\title{
Impact of Geography on Adaptation for the Future Sustainability of Human Society on Earth
}

\author{
Jones Lewis Arthur \\ Department of General Agriculture, Sunyani Technical University, Sunyani, Ghana \\ Email: jonesarthur2002@yahoo.co.uk, jonesarthur2002@stu.edu.gh
}

How to cite this paper: Arthur, J. L. (2021). Impact of Geography on Adaptation for the Future Sustainability of Human Society on Earth. Open Journal of Social Sciences, 9, 188-217.

https://doi.org/10.4236/jss.2021.93013

Received: January 27, 2021

Accepted: March 15, 2021

Published: March 18, 2021

Copyright ( 2021 by author(s) and Scientific Research Publishing Inc. This work is licensed under the Creative Commons Attribution International License (CC BY 4.0).

http://creativecommons.org/licenses/by/4.0/

\section{(c) (i) Open Access}

\begin{abstract}
Over time, societies have continued to thrive but with diverse arguments relating to the pathways for survival and whether the geography-adaptation thinking provides any lessons to engage the contemporary world in order to gain a better option for human existence. This paper explored the adaptation and survival of societies from the perspective of the corresponding interdependences between humans and the environment. It also examined how successful adaptations in the past could inform future trajectories of human societies on the Earth. The paper adopted content analysis to review adaptation as a discipline of Geography by also examining adaptation from the perspective of the future sustainability of human society on Earth. In the content analysis, both quantitatively and qualitatively approaches were used to systematically analyze written, verbal or visual documentation to provide a better understanding of how geography has informed adaptation of human societies from diverse spatial and temporal frames. The paper identified that adaptations in human-environment systems worldwide, have been influenced by environmental degradation, climate change, relationships with friendly and hostile societies, and especially, the willingness and ability of societies to recognize the need for social change and resource consumption. Also, successful adaptations of past societies have been influenced largely, by the commitment of societies to solve environmental problems, application of positive culture-oriented to the protection of the environment, use of environment-friendly technologies, and access to resources. In sustaining future societies, however, human societies must commit to addressing local and global environmental changes from a mix of experiences from both past and present societies.
\end{abstract}

\section{Keywords}

Adaptation, Geography, Sustainability, Society 


\section{Introduction}

"...how on earth could a society make such an obvious disastrous decision as to cut down all the trees on which it depended?" (Diamond, 2005: p. 415).

To survive, all societies have to adapt to the opportunities and constraints that the environment presents to them (Thornton et al., 2019). Issues of human adaptation have become critical in the current development discourse due to the lessons. It provides for effective planning of human adaptation pathways. This attempt has even become more relevant due to the contributions that geography makes towards the adaptation of human societies in space and over time.

The concept of adaptation to changing conditions created by humanity has emerged through the history of human use and abuse of ecosystems including adaptation to climate change (Pisor \& Jones, 2020), ecological transitions (Bennett, 2017) and advancement in technologies such as educational cognition (Nesterova, 2017). At the centre of these adaptations is the key lessons that geography tends to provide such as helping to offer an in-depth understanding into how human societies have adapted to the ever changing world over time.

The nature of geography provides an understanding into the conception of how the environment affects human societies, the struggle to survive, and the concept of adaptation by clarifying the relationship between humans and the environment (Adamson et al., 2018; Grzymala-Kazlowska \& Phillimore, 2018; Holling et al., 2002). Geography has advanced scholarly discourse in human-environment interactions, and processes of adaptation in different spatial and temporal scales as captured in varied publications including national and local refereed journals, proceedings of international and national conferences, symposia, as well as distinguished scholarly books.

Castree et al. (2006) among others provide important lessons to suggest that adaptation efforts have been successful partly because geography provides a clearer understanding of the different dimensions and disciplinary divides of geography for adaptation (Figure 1). It is, therefore, critical to further explore such adaptation

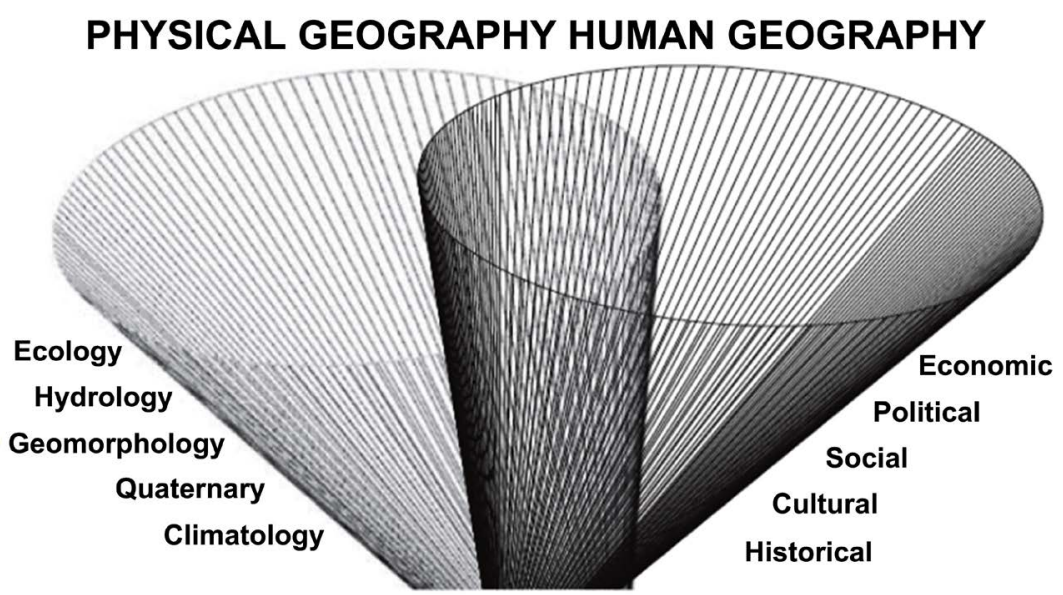

Figure 1. Multi dimensions of the disciplinary divides in geography (adopted from Castree et al., 2006). 
in order to understand the concept of geography in defining and providing pathways for assessing contemporary issues of adaptation of human societies.

Although some arguments have undermined the significant contributions of geography to human adaptation on earth, geography in-practice in the real world provides a clearer understanding of human societies and interactions with the environments as well as in promoting future sustainability of human societies on Earth (Potter \& Unwin, 2017). The Geography discipline also offers unique lessons to understand anything that is distributed across space, including the ever-changing relationship between humans and the environment; and makes predictions and even proposes solutions to current problems (Brown \& LeVasseur, 2006 Richard, 2003). In the ecological perspectives, geography is critical in the exploration of the relationships between the physical and human environments (Baerwald, 2010; Brown \& LeVasseur, 2006; Tu, 2011). This is particularly important when human-environment interdependence provides ways to ensure a balance through learning, combining experience and knowledge, and/or adjusting responses to changing systems (Folke et al., 2010). The impact of geography to human adaptations is not exhaustive as other arguments continue to cite the key roles of geography to the spatial dimensions of human adaptation (Stobbelaar \& Pedroli, 2011). But in many case scenarios of geography-adaptation studies, adapting to the environment required knowledge of how the environment works and what options of human action are feasible.

This paper, therefore, is important as this paper assesses the impact of geography on human adaptations by exploring the adaptation of human societies from time and temporal dimensions of human existence and situating same in the contemporary literary discourse so that we can gain important lessons for scholarly discourse in the fields of environmental geography. More importantly, this study critically evaluates adaptation and survival of societies from the perspective of the corresponding interdependences between humans and the environment. It also explores how successful adaptations in the past could inform future trajectories of human society on the Earth.

\section{Methodology}

The paper adopts the content analysis methodology to review adaptation as a discipline of Geography by also examining adaptation from the perspective of the future sustainability of human society on Earth. Content analysis remains one of the dominant methods as it relates strongly to the use of qualitative content analysis to interpret the symbolic construction of meanings (Neuendorf \& Kumar, 2015). The use of content analysis was useful to this study as the method linked the results of the extant literature on geography-adaptation discourse to their content or to the environment in which they were produced (Bengtsson, 2016).

Content on geography and adaptation of human-environment covered extant literature from different scales and time dimensions because it helped to assess and evaluate the contributions of geography to the adaptation of human socie- 
ties. Content analysis with both quantitatively and qualitatively approaches were used to systematically analyze written, verbal or visual documentation to provide a better understanding of how geography has informed the adaptation of human societies from diverse spatial and temporal frames (Wilson, 2016).

Through the content analysis, key frames emerge from the analysis of extant literature which was classified. The content was drawn from a variety of scope and sources; books, manuscripts, drawings, photographs, recorded conversations and online forums.

The analyses involved breaking down information obtained into conceptual chunks that are then organized into frames. Qualitative analysis was then used to develop the categories. The results were used to make inferences about the key issues and conclusions raised in the literature under broad frameworks developed from the categorization of the content in the extant literature.

\section{The Issues}

\subsection{Setting a Context for Adaptation of Human-Environment Systems}

Adaptation in the context of human dimensions of global change usually refers to a process, action or outcome in a system (household, community, group, sector, region, country) that allow the system to better cope with, manage or adjust to some changing condition, stress, hazard, risk or opportunity (Smit \& Wandel, 2006).

The term adaptation as applied to human systems is traced to the anthropologist and cultural ecologist Julian Steward, who used "cultural adaptation" to indicate subsistence activities that adjust "culture cores" (i.e. regional societies) to the natural environment (Butzer, 1989; Smit \& Wandel, 2006). Adaptation is used in this context to mean adjustments in a system's behaviour and characteristics to enhance its ability to cope with external stresses (Corrigan, 2017; Brandon, 2014; Brooks, 2003) also perceives adaptation to concentrate on three perspectives; as a process, product of an act of reception but in all cases adaptation often describes how one or more entities are reconfigured or adjusted through their relationships to one or more other texts or objects. In one stream, a geographical scientist has used paleoenvironmental science to show that societies and natural resource systems are prone to change, whether gradual (society in steady progress and change is roughly continuous and predictable) or incremental (Dearing et al., 2006; Folke et al., 2005). Arguably, the absence of progress in social and natural systems may trigger change (sudden, disorganizing, or turbulent). The change may result in an incomplete understanding of experience, prompt ambiguous actions, make the future of systems unclear and uncertain, and influence change in the environment (Folke et al., 2005; Gunderson \& Holling, 2002). Understanding the strengths and weaknesses of systems (human or environment) will positively influence and promote the understanding of processes of human adaptations on the Earth. The need to understand the transitions in 
human adaptation is critical to unveiling beter lessons for future trajectories of human adaptation.

Instability of the environment and associated systems is a tool for human adaptations on earth. Changes in the environment (including the physical and biological factors along with their chemical interactions that affect an organism) are influenced by vulnerability oriented toward responses to stress and perturbations, as well as interactions with rapid changes, whether slow or rapid (Allen \& Holling, 2010; Brooks, 2003; Miller et al., 2010). Environmental systems such as ecological processes, conditions, and changes are linked to the provision of ecological services by the natural environment. Ecological change that alters "the flow and reliability of the supply of ecosystem services that people receive from nature" can increase the vulnerability of human and ecosystems to further changes (Carpenter et al., 2006; Schoon \& Cox, 2018: p. 262). Meanwhile, the vulnerability of environmental systems is argued to be influenced by the resilience of human and environment systems. Resilience thinking, originally introduced by (Holling et al., 2002), is a concept that helps to provide an understanding of the capacity of ecosystems (with alternative attractors) to persist in the original state, subject to perturbations or disturbances (Folke et al., 2010; Sellberg et al., 2018). Geographical knowledge in resilience thinking shows that natural resource systems maintained in a healthy, productive and resilient condition help to provide a human need in a healthy environment. Resilience thinking is, therefore, important to understanding the processes to address changes in human-environment systems because it provides an understanding of the way human adaptive systems build capacity to respond to sociological changes (Sellberg et al., 2018).

The human adaptive capacity to address socio-ecological changes, and maintain an ecosystem balance is influenced by the nature and magnitude of human footprints on the environment (Blanchard et al., 2019; Folke et al., 2005; Naughton-Treves et al., 2005; Naughton-Treves et al., 2011). Adaptability as a concept in geography provides some understanding into processes to address resilience in independent human and environmental systems because, it guides human systems to cope, manage or adjust to changes (Blanchard et al., 2019; Folke et al., 2005; Folke et al., 2010). Adaptation is necessary to build knowledge and understanding necessary for human and natural systems to respond to socio-ecological changes on the Earth. These developments call for a better understanding into trends in human adaptation and the potential roles played by human societies in the context of human adaptation on the earth.

The modern use of adaptation in the global change field has its origins in natural sciences, particularly evolutionary biology (Smit \& Wandel, 2006). Adaptation in this context is more of developing genetic or behavioural characteristics that enable organisms or systems to cope, in the phase of environmental changes (Kitano, 2002). This context of adaptation presents two key issues of 1) the action or outcome of different systems (households, community, group, sector, region, country), and 2) a well-prepared collective system to better cope with, 
manage or adjust to meet some changing condition, stress, hazard, risk or opportunity. Geographical scientists have applied paleoenvironmental science to prove that, human societies have in the past millennia recognized the link between the environment and human existence (NRC, 2010; Stolton, 2010). Past societies have consciously managed the environment by protecting wilderness and wildlife from extinction (Levis et al., 2018), maintained environmental stewardship through consciousness on the formation of behavioural intentions (Martinez Garcia de Leaniz et al., 2018), and halted and retained receding landscapes, maintained timber supplies, stopped avalanches, and provided game for hunting or protected secure places where fishes breed (Stolton, 2010).

Today, human societies have adapted to the environment by conserving biodiversity and protecting species from extinction (Almond et al., 2020; Gavin et al., 2018; Robert et al., 2017). Attempts at reducing biodiversity loss have led to several measures including the development of National Biodiversity Strategies and Action plan by the 193 CBD members and convening of international environmental meetings and writings on international biodiversity-related reports and accords that set biodiversity targets (CBD, 2010; Gavin et al., 2018; Stolton, 2010). Now decisions on nature, climate, food, development, people, and life have become one of the core themes on the IUCN agenda (Thompson \& Scoones, 2009). This is mainly because decisions on nature management and use are not always fair and appropriate, nature's benefits are not equitably shared, and richer countries and social elites have become better placed to reap the benefits while poorer nations and communities bear the cost of biodiversity loss and get little or no benefit (Almond et al., 2020; Thompson \& Scoones, 2009).

Similarly, efforts at protecting the environment have prompted a restraint in the collection and consumption of wild species and their products, and establishment and expansion of the global network of parks and protected areas to include “over 12 per cent of the earth's terrestrial surface and 0.5 per cent of its marine systems" (CBD, 2010; Chape et al., 2005; UNEP-WCMC, 2008; Rands et al., 2010; Worboys \& Winkler, 2006: p. 47). PAs, now in different sizes, age, purpose, designation, governance, management, and outcomes collectively support biodiversity conservation (Table 1) (Dudley et al., 2010; Locke \& Dearden, 2005). The World Database on Protected Areas (WDPA) now recognizes 102,290 areas, covering $12.9 \%$ of the Earth's land surface as being under some form of protection (Chape et al., 2005; UNEP-WCMC, 2008). Although human adaptations have significantly led to the conservation of large ecological resources, human actions including the consumption of ecological resources continue to undermine adaptation efforts.

Globally, the competing interests of environmental conservation and development catalyzed by factors including, climate change, accelerated resource depletion, and persistent poverty makes it critical to conserving the environment (Andam et al., 2010; MEA, 2005; Rockström et al., 2009; UNDP, 2011b). For example, human activities have over the past 50 years rapidly and extensively 
Table 1. IUCN protected area categories (summarized from Dudley et al., 2010).

\begin{tabular}{|c|c|}
\hline Category & Description \\
\hline $\begin{array}{l}\text { Ia Strict Nature Reserve } \\
\text { Ib Wilderness Area }\end{array}$ & $\begin{array}{l}\text { Area strictly set aside to protect biodiversity and geological/ } \\
\text { geomorphological features; human visitation, use and impacts are } \\
\text { strictly prohibited. } \\
\text { Large unmodified or slightly modified areas: protected and managed to } \\
\text { preserve their natural condition. }\end{array}$ \\
\hline II National Park & $\begin{array}{l}\text { Large natural or near natural areas that protect large-scale ecological } \\
\text { processes and ecosystems; managed to provide a foundation for } \\
\text { environmentally and culturally compatible spiritual, scientific, } \\
\text { educational, recreational and visitor opportunities. }\end{array}$ \\
\hline III Natural Monument & $\begin{array}{l}\text { Areas set aside to protect a specific natural monument. They are } \\
\text { generally quite small and often with high visitor value. }\end{array}$ \\
\hline IV Habitat/Species & $\begin{array}{l}\text { Aimed at protecting a particular species or habitats and management } \\
\text { reflects this priority. Many need regular and active interventions. }\end{array}$ \\
\hline $\begin{array}{c}\text { V Protected } \\
\text { Landscape/seascape }\end{array}$ & $\begin{array}{l}\text { Areas where people-nature interaction over time, has produced an area } \\
\text { of distinct character with significant ecological, biological, cultural and } \\
\text { scenic value. }\end{array}$ \\
\hline VI Managed Resource & $\begin{array}{l}\text { Aims to conserve ecosystems and habitats, together with associated } \\
\text { cultural values and traditional natural resource management systems; } \\
\text { It is generally large, mostly in the natural condition with a proportion } \\
\text { under sustainable natural resource management. }\end{array}$ \\
\hline
\end{tabular}

undermined ecosystems; limits of global Climate change, rate of biodiversity loss, and nitrogen cycle (biogeochemical flow boundary) has reached critical levels; plant and animal disappearance are in the ranges of 100 to 1000 times more than the past-mainly due to growing demands for food, fresh water, timber, and fuel (MEA, 2005; Rockström et al., 2009). The increasing impacts of human activities on natural resources and consequent global changes are driving the need for human systems to reconsider its impacts on the environment, and also accept adaptation as a strategy to better cope, manage or adjust to the changing conditions of stress, hazard, risk and hopefully avoid "an obviously disastrous decision as to cut down all the trees on which it depended" (Smit \& Wandel, 2006; Diamond, 2005: p. 419). The concept of adaptability is needed to preserve the integrity of natural resources, and control human impacts on ecological systems.

\subsection{Overview of Geography}

"Geography is the study of spatial variation, of how and why things differ from place to place on the surface of the Earth (Getis et al., 2008: p. 4).

Geography as a discipline investigates how, why and where human and natural activities occur and how these activities are interconnected (Getis et al., 2008). Geography is further defined as a particular branch of learning or body of knowledge with unique defining elements (its phenomena, assumptions, concepts, theories and methods) that distinguish geography from other knowledge formation. Although different scholars define geography differently, they main- 
tain the distinct spatial characteristic of the discipline which also, distinguishes geography from other disciplines. The scope of geography focuses on the study of the nature of the environments, the location of phenomena such as settlements, and spatial distributions and relationships (Robison, 1976); the spatial organization and character of the Earth's surface; and the evolving character and organization of the Earth's surface (Strahler \& Archibold, 2008).

Geography as a discipline is complex and multi-dimensional. The discipline embraces the various fields such as economics, culture, politics, environment, geomorphology, medicine, transport in a multi-dimensional frame of the broader geography discipline (Strahler \& Archibold, 2008). The multi-dimensional and complex scope of geography is influenced by the fact that geography studies how and why things differ from place to place on the earth's surface, over time. The interdisciplinary approach of geography provides effective ways to address many world problems (since most real-world problems are complex, and lie beyond defined disciplinary margins, and cannot be fully pursued by discipline-specific scholars) (Richard, 2003). Geography with its complex and multi-dimensional scope provides an important foundation for studying complex spatial relationships-human and environment systems.

Geography divided along physical and human branches is interconnected by environmental geography (which integrates contemporary issues of human-environment interactions) (de Blij \& Murphy, 2003). Physical geography the cornerstone of geography, emphasizes the various internal and external forces such as geomorphologic, atmospheric, and hydrological processes that produce different landforms, form soil, and distribute biological elements, climate, and weather over different places (Bendix \& Urban, 2020; Getis et al., 2008; Fu et al., 2019). On the other hand, human geography deals with the study of relationships, and interactions of human beings and the environment and emphasizes the need to appreciate the diversity of people, places, and cultures, and understand the role people play in shaping our world (Fouberg \& Murphy, 2020). The uniqueness of human geography stems from the fact that it encompasses the various fields of geography such as energy, cultural, population, social, population, transport, economics, politics, history, physical geographies, and human-environment relations (Anderson, 2019; de Blij \& Murphy, 2003; Ducruet et al., 2019; Manners, 2019). The core of the various spheres of geography explores explanations into the issues of why things are where they are; how human society is structured in space; and how physical environmental systems and human activities interact (Pritchard \& Hutchinson, 2010). Geography provides a clearer link between human-environment interactions, and also the processes for either humans or environment to adapt to the changing processes of the other. Some of these conceptual links can be fully explained by evaluating the contributions made by geography as a discipline to adaptation in human and environment systems. Key to these arguments on geography and adaptations of human societies is the role that the discipline plays in the adaptability of human-environment systems. 


\subsection{Contributions of Geography to Adaptability of Human-Environment Systems}

"Geography is a study of the evolving character and organization of the Earth's surface" (Strahler \& Archibold, 2008).

Within the three main branches of geography (physical, human, and Environmental), there is enough evidence to link geography to interactions between human and environment systems. To understand such human-environment interactions, there is a need to clarify the concept of the relationship between humans and the environment. Throughout the history of modern social science, two extreme positions have been held by geography thinkers: environmental determinism and environment-as-backup (Judkins \& Marissa, 2008; Phillips, 2017). In the 1800 and early 1900s emerged scholars who argued that human and social phenomenon of interest can be explained by facts based onthe environment (Huntington, 1915; Judkins \& Marissa, 2008; Phillips, 2017). Later, this assumption was rejected by geographers who believed that real truth about nature cannot be explained beyond what human societies have constructed through discourse (environmental-as-backdrop or post-modernist theories) (Durkeim, 1995; Minca, 2001; Phillips, 2017; Soper, 1995). The balance of these arguments guides humanity in our approach to influence or adapt to the environment, and provides the underlying arguments for studying human-environment interactions.

Borrowing from (Strahler \& Archibold, 2011); geography is about the active roles played by spatial analysis, and human-environment interactions in inquiries related to space, place, interactions, and organization of the Earth's surface. The three branches of geography (physical, human, and environmental) interact in the real world of study to directly link human and natural resource interactions of different places Getis et al. (2008). The interaction of the branches provides an understanding of the reasons and processes of mitigation for different phenomenon on the Earth surface. Geography's spatial perspective is critically linked to issues of location, regions, place, movement, landscape, and interaction between humans and the environment (de Blij \& Murphy, 2003; Mabogunje, 2015). For example, studies in both crustal movements (in the earth's crust) and gradational processes (surface changes) provide some understanding into the formation of mountain, valley, rock and soil formation, and how they influence weather and climatic patterns (Getis et al., 2008; Lee et al., 2015). In recognition of the need to ensure a balance for human-environment interactions, physical and human geographers must actively collaborate in efforts to address critical human impacts on the environment (Kemp et al., 2015; Liverman \& Vilas, 2006). Therefore, geography provides the needed knowledge to guide human systems to adapt to environmental changes and reduce the associated adverse impacts of human systems on the environment.

Geography employs geographical knowledge to "record, analyze and store information about the spatial distribution and organization of conditions (both naturally occurring and humanly created) that provide the material basis for the 
reproduction of social life", and underlie man-spatial interrelationship (Borrini-Feyerabend et al., 2006; Harvey, 1984: p. 2; Kirby et al., 2017). Technological advancements in remote sensing and earth observation, Geographical Information System (GIS), Global Positioning Systems (GPS), and geospatial visualization in studies including forest operations and road network planning (Grigolato et al., 2017), modernizing agriculture (Durand \& Fournier, 2017) have enabled extensive growth in geographical sciences over the past two decades (NRC, 2010). The increasing accessibility of GIS has made it possible for decisions on the environment to be based on remotely sensed observations (Heiko, 2009). Hitherto, significant information on projections of climate change impacts on humans that were unavailable can now be accessed with precision. Geographic tools have provided information on human impacts on biophysical systems and facilitated the processing, analysis, and representation of geographical data for various uses (NRC, 2010; Reyes-García et al., 2016). As a result, geographic tools for data collection provide the medium for the collection of data on human-environment interaction over time and space and assists in making critical decisions in evaluating human footprints on global environmental systems in order to help curb the adverse impacts of humanity on the environment.

Geography under conservation decision making provides the platform to discuss governance (power relationships, decision-making processes, and accountability) of natural resources (Newman et al., 2017; Scarlett \& Boyd, 2015). Geography has provided a forum to discuss issues of bio-prospecting, carbon trading, protected areas, and creation of a theoretical and empirical framework that assess human-environment systems (Liverman, 2004). Human-environment interrelationships and spatial differentiation can provide a more regionally detailed analysis of the causes and effects of global environmental change including climate change, and the regimes that respond to the changes (Liverman, 2004; von Seggern, 2021). Geographers provide expertise to influence, reform, or replace institutions with other organizations that incorporate greater representation for civil society, and support treaties that provide enforceable and equitable regimes to tackle critical environmental challenges such as climate change, biodiversity loss, and environmental protections (Liverman, 2004). Geographic platforms can be opportunities for geographers to bring their experience to bear on the process to apply environmental best practices to influence efforts at reducing human impacts on the environment.

\subsection{How the Environment Adapts to Human Impacts}

"The earth is finite. Its ability to absorb wastes and destructive effluent is finite. Its ability to provide food and energy is finite. Its ability to provide for growing numbers of people is finite. And we are fast approaching many of the earth's limits".

The environment reacts to human impacts when the stability of the environmental system, usually over long periods of human impacts, becomes weak. The 
environment as part of the process of adapting to human impacts weakens the stability as well as the carrying capacity of natural systems, further increases human vulnerabilities to the weakened systems of the environment, and undermines the processes for human adaptation to environmental changes (Gunderson \& Holling, 2002; Hoegh-Guldberg et al., 2018). The environment either in a subtle or violent reaction adapts to human actions. The nature of human impacts on the environment produces either a minimal (gradual loss of species quality and warming of surface temperature with implications for the melting of polar ice, and increase in disease prevalence) or extreme (extreme cases of quality of vegetation and animal species, permanent loss of surface ice in the polar regions, flooding, earthquakes, and sometimes the ultimate collapse of human societies) reaction from the environment (Diamond, 2005; Andam et al., 2010; CBD, 2010; Rockström et al., 2009; Rossman, 2006; Tellman et al., 2018). Some desert regions of Australia and Africa are the direct results of the environment adapting to the continuous destruction of surface vegetation by human societies. In these areas as well, human habitation has been reduced substantially and to some extent, totally halted (Diamond, 2005). Hence, it is significant to address the adverse human impacts on the environment because the environment may react and adapt to human impacts through increase incidence of flooding, earthquakes, and extinction of species. Further insights into human adaptations to the environment is important in providing additional facts to support the impacts of geography to adaptation of human societies.

\subsection{Human Adaptation to the Environment: The Balance of Drivers, Impacts and Actions}

What is driving the impacts?

"Human activities have become globally interconnected and intensified through new technology, capital markets, and systems of governance, with decisions in one place influencing people elsewhere" (Folke et al., 2005: p. 442).

Geographers have used paleoenvironmental data to establish that, human societies have experienced a trajectory of vulnerability, beginning with highly vulnerable societies of hunters and gatherers, through periods of less vulnerability, to a well-buffered and highly productive agrarian-urban societies, to a world with regions of extreme overpopulation and overuse of life-support systems (NRC, 2010; Messerli et al., 2000). Modern societies will have had to change their consumption patterns and adapt to changing environment systems because vulnerability to environmental changes and extreme events have increased.

Geographical knowledge on conservation and development shows that modern societies still depend on the extraction of both renewable (like wood, fish, water) and non-renewable (e.g. oil, gas, and metals) natural resources. Humanity depends on the natural environment, including energy for industries, food and water for consumption, and tools for our work for "life" (Diamond, 2005; D'Odorico et al., 2018; Goudie, 2018). Societies' commitment to extract natural resources 
have raised concerns on where, in what amounts, and by what means we choose to do so. Surprisingly, human impacts on the environment are breeding dire consequence for humanity today because; "past people were neither ignorant bad managers who deserved to be exterminated or disposed of, nor all-knowing conscientious environmentalist who solved problems that we can't solve today" (Diamond, 2005: p. 10).

The relationship that societies have with the biophysical environment

Human actions create adverse implications on the biophysical environmentsymbiosis between the physical environment and the biological life forms within the environment and include all variables that comprise the Earth's biosphere. The biophysical environment divided into natural and built environments is the source of societies' basic raw materials for human existence, and also provides opportunities for societies to develop ways of utilizing those materials (Pauliuk \& Hertwich, 2015; Rossman, 2006). But, the availability of these resources varies geographically. Information from Paleoenvironmental science shows that the capacity for natural resource systems to maintain a human-environment balance are influenced by environmental damage, climate change, actions of hostile and friendly neighbours, and significantly, the society's responses to environmental problems (Galvani et al., 2016; O'Connell, 2017). In the past 50 years, ecosystems have been rapidly and extensively undermined by human impacts; and plant and animal disappearance are in the ranges of 100 to 1000 times more than the past mainly due to growing demands for food, fresh water, timber, and fuel (MEA, 2005; Rockström et al., 2009). The arguments of (Rockström et al., 2009) are to the effect that human impacts such as limits of global climate change, rate of biodiversity loss, and nitrogen cycle (biogeochemical flow boundary) on the environment have reached critical levels. Presently, it is widely anticipated that human-induced changes to the climate are likely in the next century if not apparent already, to have significant implications for societies and economies (Bulkeley \& Newell, 2015; Houghton et al., 1996; Smit \& Wandel, 2006; Thomas, 2017). Humans' impacts have adversely damaged the environment such that, the damage to the environment has transgressed "safety" limits.

Relationships with other societies, both friendly and hostile

The interaction between societies and their neighbours can significantly undermine the natural environment. Historical geography that explores the study of the human, physical, fictional, theoretical, and "real" geographies of the past, has proved that hostile societies essentially kill people, disrupt social organizations, and plunder resources whilst friendly societies provide resources, and enhance societal survival through trade (NRC, 2010; Rossman, 2006). Societies exploit their natural resources to improve their strength to resistance or risk physical destruction (through wars) especially when it has hostile neighbours (Diamond, 2005). For example, there was massive destruction of natural resources by wars including, the atomic bombing of Hiroshima and Nagasaki (during the Second World War in Aug 1945) led to adverse environmental impacts (Hogan, 
1996). I interest for scarce natural resources is believed to have driven people to wars that destroyed wildlife and wilderness areas, as well as cultural, historical, and spiritual values of the society (Boquet, 2017; David Hollenbach, 2019; Diamond, 2005; Nelson, 2010). Similarly, the activities of friendly societies such as import trade have encouraged the overexploitation of natural resources in the exporting society (Diamond, 2005). The geography of neoliberalism including, a subtle agenda by the development world to promote trade and development in developing nations have driven massive destruction of wildlife and wilderness areas, and marine resources in many African countries such as Nigeria (Liverman, 2004; Liverman \& Vilas, 2006; Nelson, 2010). The prioritization of societal interests is important for human survival since the relationship with friendly and unfriendly societies can lead to the destruction of the environment that supports survival.

The willingness and ability of society to recognize the need for social change and resource consumption

The responses of societies to environmental problems have significantly impacted on environmental systems because different societies respond differently to similar problems. Paleoenvironmental science has proven that failure or success of many societies (past and present) is contingent on societal response to their problems. The Tikopia, Tonga societies in Japan, Dominican Republic, Israel, and the Netherlands overcame their environmental problems by developing successful environmental strategies such as effective forest management, wildlife conservation, water capture, and creation of dykes to control water (Diamond, 2005; Naughton-Treves et al., 2005; Nelson, 2010). Successful human societies were proactive in adapting to solve their environmental problems (Schoon \& Cos, 2018; Zhang et al., 2019).

\subsection{Human Adaptations to the Environment}

\section{Human adaptation to changes in the environment}

As articulated by Diamond... "On the ground, one can stand on the border at many places, face east, and look into pine forest, then turn around, face west, and see nothing except fields almost devoid of tree" (Diamond, 2005: p. 329).

Much attention on human-environment interactions through time has focused on well-documented case-studies particularly, the use of archaeological records to demonstrate societal collapse through vulnerability to climate change, environmental maladaptation or a mixture of both (Brandon, 2014; Diamond, 2005; Redman, 1999). Although previous researches have documented shifts in climate, soil erosion, habitat loss, and water degradation, the role of humanity in these changes are often inadequately understood such that; it hinders the ability to predict the magnitude and timing of future change (Dearing et al., 2006; NRC, 2010). Historical geography provides key learning experiences for adaptation because past records about long-term sustainability and management of ecosystems and services show that individuals and societies have in the past adapted to 
environmental changes (Adamson et al., 2018; Scarano, 2017). In these experiences, adaptations to environmental changes are either initiated by individuals (when triggered by individual extreme events) or the governments on behalf of society, in anticipation of change or in response to individual events (Allen \& Hoiing, 2010). The sections that follow treat adaptation from a mix of individual and societal perspectives.

\section{Contemporary human adaptations to the environment}

Geographical knowledge including conservation decision making on humanenvironment interaction has helped to reduce, stop, and reverse human impacts on the environment (NRC, 2010). Efforts to reduce natural resource depletion (including biodiversity), restore ecological integrity, and address cultural, religious, and spiritual values of the environment have led to the development of National Biodiversity Strategies and Action Plans, and biodiversity targets (Aichi Accord) (CBD, 2010; Rands et al., 2010). These environmental actions have supported efforts to halt biodiversity loss and secure the planet's variety of life, improve human well-being, and support poverty eradication (CBD, 2010). Besides, humans have established and expanded global networks of parks and protected areas to include “over 12 per cent of the earth's terrestrial surface and 0.5 per cent of its marine systems" (Chape et al., 2005; UNEP-WCMC, 2008; Worboys \& Winler, 2006: p. 3). These efforts have led to the regulation of wildlife exploitation, wilderness destruction, and protection of the ecological integrity including the cultural, religious and spiritual values of natural resource areas. Human adaptation to changes in natural resources systems has worked to halt species loss, restore ecological systems, and provide effective conservation action for biodiversity, worldwide (Marciniak \& Perry, 2017; Scarano, 2017).

Again, humans have adapted to the environment by recognizing and integrating human needs (including sustainable social and economic development) with environmental conservation plans. The 2002 UN Summit on Sustainable Development (WSSD) catalyzed environment and development-oriented movements to explore collaboration between biodiversity conservation and human development (Holland, 2012). The priorities for the framework have included issues on sustainable development of water and sanitation, energy, health and environment, agriculture, biodiversity and ecosystems. On the environmental fora, geographers have influenced discussions and decisions to prioritize biodiversity conservation in a broader framework of conservation and socio-economic development context of human societies. The actions to prioritize conservation needs are motivated by the fact that the impact of biodiversity loss on human development is severe in many tropical developing countries, where poor communities rely heavily on natural resources (UNDP, 2011b). Moreover, global poverty trends are not getting better as one of the key millennium development goals (MDGs) indicates that we still have over a billion hungry people (UNDP, 2011b). Global poverty estimates show that an additional 64 million people will have fallen into extreme poverty by the end of 2010 (UNDP, 2011a). At the 
broadest level, poverty links biodiversity as a means of providing inputs into poor peoples' livelihoods; and as a "buffer against risks and shocks, helping smooth livelihoods and consumption patterns" provide a forward momentum for conservation to be explicitly connected to development (Timmer \& Juma, 2005; CBD, 2010: p. 13). The approach to adapt and effectively project conservation and development goals would require a commitment to link the two goals to local initiatives, ensure win-win solutions for synergistic solutions to be advanced, and or tradeoffs made between biodiversity and development goals.

Human adaptation to the environment has involved the application of effective institutional arrangements (formal and informal) to support governance of natural resource systems. Governance of natural resources (power arrangements, decision making, and accountability of stakeholders) ranges "from the traditional exercise of government authority, through to a wide variety of partnership, co-management and informal arrangements involving multiple agencies, NGOs, communities, and individuals" (Borrini-Feyerabend et al., 2006; Graham et al., 2003; Kothari, 2006; Lockwood, 2010: p. 762). Governance of natural resource management has resulted in the application of effective policy formulation, institutional reforms, increased stakeholder involvement including, local and community involvement to reduced human impacts on the environment (Arthur, 2021). For example, policy and legal reforms carried out in Tanzania in the 1990s enabled local communities to formalize collective actions in forest management to support widespread ecological recoveries (Nelson, 2010). Again, centralized PA governance in Kenya in 1970 has made Kenya the only country in East and Southern Africa with a sizeable wildlife population because; commercial hunting of wildlife is barred (Balaton-Chrimes, 2021). Governance of environmental resources improves laws and policy, broadens local community participation in environmental management, promotes biodiversity conservation, and supports strategies that help humanity to adapt to the environment.

Human adaptation to the environment has effectively mobilized knowledge for environmental management. The mobilizing of knowledge about environmental systems has brought together expert ideas to influence, reform, or replace institutions with organizations that have greater representation for civil society. Today, geographical scientist are using GIS, geospatial visualization, and paleoenvironmental data through the use of tree rings and fossilized pollen, to analyze changes to the physical processes and patterns over time, develop and reconstruct long term environmental history, and in a way establish the relative contributions of the physical and the human context of environmental change (NRC, 2010; Plumpton et al., 2020). Geographical knowledge, for example, has led to "record, analyze and store information about the spatial distribution and organization of conditions (both naturally occurring and humanly created) that provide the material basis for the reproduction of social life" (Harvey, 1984: p. 2). Environmental experts have also promoted treaties that provide enforceable and equitable regimes to prevent critical environmental challenges such as cli- 
mate change, biodiversity loss, and weak environment laws (Liverman \& Vilas, 2006; Lockwood, 2010). Conservationists are actively influencing decisions at both local and international levels, to ensure that issues of ecological conservation and restoration are incorporated into all facets of human life (Baerwald, 2010). Geographical knowledge including environmental best practices provides the needed expertise to provide useful inputs into human adaptations.

Human adaptations to the environment have been improved by improvements in clean and advanced technologies (Liu et al., 2018; Gruda et al., 2019). Technological advancements have increased efficiency and provided good alternatives to exploit natural resources. Improvement in geographic tools for data collection such as satellite imagery, and GIS has been used to assess and conduct spatial analysis into the geographic phenomenon, map species diversity and habitat trends over time, conduct ecosystem overviews, and enhance forest cover dynamics for improved resource management (NRC, 2010; Pritchard \& Hutchinson, 2010; Timmer \& Juma, 2005). Advancement in geographic tools of data collection has improved processes to predict species trends, and establish better understanding into how human adaptation can effectively apply in our everchanging environment.

\subsection{How Successful Adaptation of Societies in the Past Might Influence Future Trajectories}

\section{Commitment to solving environmental problems}

Societies that survived in the past committed to solving their environmental problems. These societies overcame their environmental problems by adopting a bottom-up, and top-down approaches to solving environmental problems at the individual, and societal levels (Diamond, 2005). At the individual level, bottom-up decision making translated into a collective objective of reducing challenges in the environment (Carolus et al., 2018; Diamond, 2005; Tseng et al., 2018). The top-down approach has also been useful in addressing the environmental challenges of large societies with a centralized political organization, including playing important role in the Swedish government's climate policy decision-making process (Krook-Riekkola et al., 2017). Tokugawa society of Japan used the top-down approach to effectively reduce deforestation and soil erosion, improve soil fertility and conservation of water resources, and regulate fishing and hunting (Diamond, 2005). Applying both bottom-up and top-down strategies of decision making can promote sustainable consumptions, effective adaptation, and consequently solve many societal problems.

To sustain future societies, geographers must spearhead conservation and development decision making processes including, the top-down and bottom-up approaches in the management of Earth's environmental resources (NRC, 2010). Human societies should continue to spearhead local level decisions making processes to encourage local communities to regulate land use patterns, prevent the destruction of vegetation and introduction of alien species, reduce atmos- 
pheric gases, and prevent the disposal of toxic substances into the environment (Diamond, 2005; Nelson, 2010). At the international level, top-down decision making such as international conventions and agreements must continue to provide a platform to engage multi-stakeholders including, geographers in decisions and actions that regulate human activities on the Earth (Talberg et al., 2018). These actions should include the expansion of effort to control greenhouse gas emissions, and disposal of toxics, engage timber companies in multi-scale tree planting to capture carbon, improve developments in aquaculture, manage global climate change, and reduce the proliferation of nuclear weapons, world insecurity and biodiversity loss (Diamond, 2005; Page, 2005; Rands et al., 2010; UNDP, 2011a). Enforcement of environmental management actions should be pursued at both global and local levels. To sustain future societies, we have to apply appropriate decision making processes to solve environmental problems (especially global issues of climate change, sea-level rise, and melting of polar ice) at the local and global levels.

\section{Cultural orientation receptive to adaptation}

Cultural orientation has played significant roles in the survival of past societies. Culture (the characteristics of a particular group of people, defined by everything from language, religion, cuisine, social habits, music and arts) mediates the constraints and opportunities provided by the shared environment (Yang et al., 2018). Humans have a unique culture that supports a wide range of adaptations to the environment. Human culture helps to create better tools, allow people to spread across the world, and dominate the world's plant and animal life like no other creature (Boyd et al., 2011). In many past societies, culture greatly influenced adaptation, and subsequent survival of these societies (Boyd, 2017; McGovern, 2000). For example, the Tokugawa society had a culture friendly to the environment and contributed to the successful adaptation of their society. The Tokugawa people practised Buddhism which showed a strong love for nature; had an ecological robust landscape that supported rapid tree growth; used volcanic ash and Asian dust to restore fertility to the land; refused to keep goats and sheep to protect vegetation; and recognized their long term stake in preserving their forest (Diamond, 2005). Similarly, the tiny Pacific island of Tikopia had a culture that regulated population through an orientation to zero population growth; use of contraceptives, abortion, infanticide, celibacy, suicide, and dangerous adventurism (Diamond, 2005).

Evidence from historical geography-studies geographical patterns through time, including how people have interacted with their environment and created the cultural landscape, particularly the love for nature, land use patterns, and consumption patterns have provided information about the critical roles of culture in regulating the actions of many societies. It is evident that societies that failed in their survival resorted to wars to solve internal problems, overexploited and destroyed the environment in the hope of providing the need of the populace, and refused to learn and adapt to change in the globally changing environ- 
ment (Boyd, 2017; Diamond, 2005). On a future trajectory of survival, societies will need to explore and uphold cultural practices that improve the levels of environmental consciousness, and ecological stewardship and also commit to transform and re-orient to changing needs of the environment. Future societies would have to accept change beyond cultural limitations because the socio-cultural dimensions of natural resources use will be central to the causes and effects of land-cover and land-use changes for future societies.

\section{Technological acceptance}

Technology introduces efficiency in resource use and conversely, results in greater degrees of resource depletion (Altieri et al., 2017; Costantini et al., 2017; Rossman, 2006). Evidence has proved that innovations in technology, and acceptance of available technologies including improved tools for fishing, and improved farming practices had influenced strategies for successful adaptation of past societies. The Inuit in Greenland adapted to effective technology packages such as kayaks and harpoons for hunting and fishing imported by the Norse (also of Greenland) from Europe. Unlike the Inuit, the Norse were xenophobic who considered the Inuit as heathens with poor ways of life, refused to learn from them, and never adopted technologies like kayaks and harpoons which had the potential to enable more effective exploitation of food resources during the Little Ice Age (Diamond, 2005; Rossman, 2006).

In today's world, technology has become an important tool for regulating nearly, all aspects of human life. Although technology has spearheaded massive losses of life through, clearance of large forested areas at faster rates, and polluted rivers through dredging and seepage of chemicals, it is still considered one of the critical tools of survival for future societies (Costantini et al., 2017; MEA, 2005; Rockström et al., 2009). Today GIS and geospatial mapping power geographical tools to monitor and manage species dynamics, and monitor and apply species mapping to regulate and predict future trends in species (Turner, 2003). The path to sustaining societies for the future will demand the use of geographical tools such as GIS, and spatial mapping, predict species trends and provide relevant information and inputs into human adaptations.

Social stratification and power

Social stratification (class, status and party-political party relations) and power (to regulate access to land and capital, social respect, physical strength, and intellectual knowledge) play important roles in the success of adaptation for many societies (Barnes et al., 2017). Information from historical geographers shows that the greed for power and domination formed the core of human nature. Individuals abused power, and controlled and monopolized natural resources to gain significant control of their delicate communities. Early social classes consolidated their power over societies by creating laws that strengthened social stratification, and passing on control of society (by hereditary) to individuals who do not necessarily merit them (Sherman, 1991). The survival of the Roman Republic, and Greek civilization, was influenced by both political stability and 
somewhat fair social stratification. The Roman Republic exercised control over the society through strata that consisted of the Consul, Senate, Assembly of Centuries, and Assembly of Tribes (Sherman, 1991). Social stratification and power arrangements help to appropriate roles and responsibilities, and decision-making processes to support the adaptation of societies on the Earth.

The world today is still stratified along various divides such as the rich and the poor, the elite and the commons, developed and developing, and privilege and underprivileged. We live in a world deeply divided by social barriers such as race and class. These divides continue to determine the ownership, control and regulation of access to education, capital, power, natural resource use, and land tenure arrangement. Social stratification and power are important in regulation access and control of natural resources and contribute to the defeat of the concept of "tragedy of commons" (such as the depletion of a shared resource by individuals, acting independently and rationally according to each one's self-interest) (Hardin, 1998; Ostrom et al., 1999). Today, geographical knowledge in conservation, development, and environmental governance has provided experiences to regulate issues of natural resources use, the commodification of nature, and reworking of environmental governance (Liverman, 2004; Liverman \& Vilas, 2006; Kemp et al., 2015). These attempts would ensure that powerful states like China are not allowed to use the excuse of supporting development to deplete forest stocks in weak and poor developing countries of Africa. The effort to sustain future societies should involve the active application of geographical knowledge in environmental governance, conservation, and development to regulate resource access, control, and exploitation for the collective interest of all race and class in the society.

\section{Availability and proximity to resources and other societies}

Availability and proximity to natural resources have an important role to play in successful adaptations because societies need to make resources available for especially, the food requirement of expanding societies (NRC, 2010). Access to resources was central to the destruction of many past societies especially, societies fought by hostile neighbours, or exploited by friendly neighbours through trade (Diamond, 2005; Rossman, 2006; Sherman, 1991). The Roman Empire was significant in this perspective, as it continued to form alliances, strengthen its social structures (distinctive, stable arrangement of institutions whereby human beings in a society interact and live together) for efficiency, and continued its conquest of other societies (Barnes et al., 2017; Sherman, 1991). Access to trade engagements enables societies to gain access to vital resources, increases surplus, and encourages territorial expansion to gain control over the lucrative trade routes (Levtzion \& Spaulding, 2003). For example, Old Ghana Empire or Wagadou Empire challenged by poor access to natural resource, expanded its routes of trading, created wealth for the people as the(empire grew rich from the trans-Saharan trade in gold and salt, and maintained its access to resource needs of its society through trade (Levtzion \& Spaulding, 2003). Resource availability 
through trade or forceful conquest provided important opportunities for adaptation of past societies and sustained their growing populations.

In contemporary times, availability and proximity to natural resources continue to play important roles in the sustenance of societies. Today, ensuring the availability of food resources to feed Earth's expanding population is one of those challenges for sustainable cities because starvation currently occurs not because of global food scarcity but as a result of unequal geographical circumstances and inefficient or unfair food distribution systems (NRC, 2010). Breakthroughs in transportation, efficient resource exploitation, world trade, and multi-national development concepts have made a range of resources available, worldwide. Now, Canadian mining companies are in Latin America mining minerals, just as China has engaged many African countries in the prospecting of oil, gold, and diamond (Levtzion \& Spaulding, 2003; Mlambo, 2019; Wegenast \& Schneider, 2017). Hitherto control of such resources would have led to wars of conquest (Gordon \& Webber, 2008; Tull, 2006). The improvement in resource access is not enough for our societies to rest on our oars as in recent times because, resource access and proximity have led to wars in Kuwait-Iraq, Angola, Sudan, Libya, and Congo. The effect has had dire implications on human life and weakened the foundations of many societies (Economides, 2000). The survival of future societies would, therefore, require a fair and efficient trading arrangement, and improvements in technologies that enhance resource availability and access to address resource deficiencies at the local and global levels.

The complex nature of social organization and dynamics

Complex societies are characterized by complex decision-making, high information flow, great coordination of parts, formal channels of command, and efficient resource production. Complex social organizations can produce public goods like defence, provide economic security, and intangibles like an interesting lifestyle, and distribute powers of a race (along with the drive of elites to secure special privileges), and to an extent the designed purpose of countering fluctuations and deficiencies in production (Boyd, 2017). In the past, Kanama in Rwanda, and Balaguer in the Dominican Republic were successful in adaptation because, the complex social organization was able to build resilience against increasing populations, increased ethnocentrism, poor environmental practices, and poor policy (Diamond, 2005). Successful adaptations in the past substantially involved societies who took advantage of the complex social organization to build resilience against problems that challenged its very existence.

Today's world is faced with complex issues of the global loss of biodiversity, climate change, Green House Gas (GHG) emissions, and conflicts of natural resources (Carlson et al., 2017; Le Billon, 2018; MEA, 2005). A complex society is therefore an important platform for an effective solution. Geographical sciences have an advanced understanding of the impacts of globalization, migration, environmental circumstances, land use, economics, and government policy on health and the spread of infectious diseases to guide adaptation to the complex 
global and local environmental problems (NRC, 2010). Complex systems and dynamics including densely populated settlements, food and labour surplus controlled by an elite, specialization of labour and craft production, a system of recordkeeping, monumental public works, and social stratification have become important remedies for addressing global challenges, and prioritizing effective humanenvironment interrelationships for future societies (Boyd et al., 2011). Effective complex social system and dynamics that prioritize opportunities for incorporating system efficiencies would provide important inputs to sustain future societies.

\section{Conclusion}

This paper evaluated the contributions of geography as a discipline to the study of adaptation of human societies from space and temporal dimensions situating same in the contemporary literary discourse. More importantly, this study critically evaluates adaptation and survival of societies from the perspective of the corresponding interdependences between humans and the environment. It also explores how successful adaptations in the past could inform future trajectories of human society on the Earth.

The paper identified among others that, the application of geographical concepts, enquiries, and tools for gathering information on human spatial interactions is significant to understanding issues of adaptation on the Earth. The geography discipline is, therefore, any important tool for the effective assessment of human adaptation. The paper further indicated that adaptations in human-environment systems worldwide, have been influenced by environmental degradation, climate change, relationships with friendly and hostile societies, and especially, the willingness and ability of societies to recognize the need for social change and resource consumption. In this vein, human adaptations to the environment have included global efforts at biodiversity conservation, recognition and integration of human needs into environmental conservation plans, and advancement in concepts and practices of promoting and applying effective natural resource management.

Successful adaptations of past societies have been influenced largely, by the commitment of societies to solve environmental problems, application of positive culture-oriented practices that protect the environment, use of environmentfriendly technologies, and access to resources. In sustaining future societies, however, human society must commit itself to address local and global environmental changes from a mix of experiences from both past and present societies. For effective adaptation of human societies, people would have to explore opportunities provided by geographical knowledge, perspectives, and tools to effectively address both local and international scale environmental problems, and apply effective technologies receptive to the changing environment and support the collective interest of all human societies on the Earth.

\section{Conflicts of Interest}

The author declares no conflicts of interest regarding the publication of this paper. 


\section{References}

Adamson, G. C., Hannaford, M. J., \& Rohland, E. J. (2018). Re-Thinking the Present: The Role of a Historical Focus in Climate Change Adaptation Research. Global Environmental Change, 48, 195-205. https://doi.org/10.1016/j.gloenvcha.2017.12.003

Allen, C., \& Holling, C. (2010). Novelty, Adaptive Capacity, and Resilience. Ecology and Society, 15, 24. http://www.ecologyandsociety.org/vol15/iss3/art24/ https://doi.org/10.5751/ES-03720-150324

Almond, R. E. A., Grooten, M., \& Peterson, T. (2020). Living Planet Report 2020: Bending the Curve of Biodiversity Loss.

Altieri, M. A., Nicholls, C. I., \& Montalba, R. (2017). Technological Approaches to Sustainable Agriculture at a Crossroads: An Agroecological Perspective. Sustainability, 9, 349. https://doi.org/10.3390/su9030349

Andam, K. S., Ferraro, P. J., Sims, K. R., Healy, A., \& Holland, M. B. (2010). Protected Areas Reduced Poverty in Costa Rica and Thailand. Proceedings of the National Academy of Sciences of the United States of America, 107, 9996-10001. https://doi.org/10.1073/pnas.0914177107

Anderson, B. (2019). Cultural Geography II: The Force of Representations. Progress in Human Geography, 43, 1120-1132. https://doi.org/10.1177/0309132518761431

Arthur, J. L. (2021). The Impact of Capacity Building on Community Leadership for Busy Communities Impacted by Dam Construction. African Geographical Review, 1-25. https://doi.org/10.1080/19376812.2020.1866044

Baerwald, T. J. (2010). Prospects for Geography as an Interdisciplinary Discipline. Annals of the Association of American Geographers, 100, 493-501.

https://doi.org/10.1080/00045608.2010.485443

Balaton-Chrimes, S. (2021). Who Are Kenya's 42(+) Tribes? The Census and the Political Utility of Magical Uncertainty. Journal of Eastern African Studies, 15, 43-62. https://doi.org/10.1080/17531055.2020.1863642

Barnes, M. L., Bodin, Ö., Guerrero, A. M., McAllister, R. R., Alexander, S. M., \& Robins, G. (2017). The Social Structural Foundations of Adaptation and Transformation in Social-Ecological Systems. Ecology and Society, 22, 16. https://doi.org/10.5751/ES-09769-220416

Bendix, J., \& Urban, M. A. (2020). Nothing New under the Sun? George Perkins Marsh and Roots of US Physical Geography. Annals of the American Association of Geographers, 1-8. https://doi.org/10.1080/24694452.2020.1761769

Bengtsson, M. (2016). How to Plan and Perform a Qualitative Study Using Content Analysis. NursingPlus Open, 2, 8-14. https://doi.org/10.1016/j.npls.2016.01.001

Bennett, J. W. (2017). The Ecological Transition: Cultural Anthropology and Human Adaptation. New York: Routledge. https://doi.org/10.4324/9781351304726

Blanchard, C., Durussel, C., \& Boteler, B. (2019). Socio-Ecological Resilience and the Law: Exploring the Adaptive Capacity of the BBNJ Agreement. Marine Policy, 108, Article ID: 103612. https://doi.org/10.1016/j.marpol.2019.103612

Boquet, Y. (2017). Environmental Challenges in the Philippines. In The Philippine Archipelago (pp. 779-829). Cham: Springer. https://doi.org/10.1007/978-3-319-51926-5 22

Borrini-Feyerabend, G., Johnston, J., \& Pansky, D. (2006). Governance of Protected Areas. In M. Lockwood, G. Worboys, \& A. Kothari (Eds.), Managing Protected Areas: A Global Guide (pp. 116-145). London: Earthscan.

Boyd, R. (2017). A Different Kind of Animal: How Culture Transformed Our Species (Vol. 46). Princeton, NJ: Princeton University Press. 
https://doi.org/10.2307/j.ctvc7799z

Boyd, R., Richerson, P. J., \& Henrich, J. (2011). The Cultural Niche: Why Social Learning Is Essential for Human Adaptation. Proceedings of the National Academy of Sciences of the United States of America, 108, 10918-10925.

https://www.pnas.org/content/108/Supplement 2/10918

https://doi.org/10.1073/pnas.1100290108

Brandon, R. N. (2014). Adaptation and Environment. Princeton, NJ: Princeton University Press.

Brooks, N. (2003). Vulnerability, Risk and Adaptation: A Conceptual Framework. Tyndall Centre Working Paper No. 38, Norwich: Tyndall Centre for Climate Change Research.

Brown, B., \& LeVasseur, M. (2006). Geographic Perspective Content Guide for Educators. National Geographic Society.

Bulkeley, H., \& Newell, P. (2015). Governing Climate Change. London: Routledge. https://doi.org/10.4324/9781315758237

Butzer, K. (1989). Cultural Ecology. In G. Gaile, \& C. Willmott (Eds.), Geography in America. Columbus: Merrill Publishing Co.

Carlson, K. M., Gerber, J. S., Mueller, N. D., Herrero, M., MacDonald, G. K., Brauman, K. A. et al. (2017). Greenhouse Gas Emissions Intensity of Global Croplands. Nature Climate Change, 7, 63-68. https://doi.org/10.1038/nclimate3158

Carolus, J. F., Hanley, N., Olsen, S. B., \& Pedersen, S. M. (2018). A Bottom-Up Approach to Environmental Cost-Benefit Analysis. Ecological Economics, 152, 282-295.

https://doi.org/10.1016/j.ecolecon.2018.06.009

Carpenter, S., Bennett, E., \& Peterson, G. (2006). Scenarios for Ecosystem Services: An Overview. Ecology and Society, 11, 29. https://doi.org/10.5751/ES-01610-110129

Castree, N., Demeritt, D., \& Liverman, D. (2006). Introduction: Making Sense of Environmental Geography. In N. Castree, D. Demeritt, \& D. Liverman, A Companion of Environmental Geography (pp. 1-16). Sussex: Blackwell.

https://doi.org/10.1002/9781444305722.ch1

Chape, S., Harrison, J., Spalding, M., \& Lysenko, (2005). Measuring the Extent and Effectiveness of Protected Areas as an Indicator for Meeting Global Biodiversity Targets. Philosophical Transactions: Biological Sciences, 360, 443-455.

http://www.jstor.org/stable/30040906

https://doi.org/10.1098/rstb.2004.1592

Convention on Biological Diversity (CBD) (2010). Linking Biodiversity Conservation and Poverty Alleviation: A State of Knowledge Review. CBD Technical Series, No. 55.

Corrigan, T. (2017). Defining Adaptation (pp. 23-35). New York: Oxford University Press. https://doi.org/10.1093/oxfordhb/9780199331000.013.1

Costantini, V., Crespi, F., \& Palma, A. (2017). Characterizing the Policy Mix and Its Impact on Eco-Innovation: A Patent Analysis of Energy-Efficient Technologies. Research Policy, 46, 799-819. https://doi.org/10.1016/j.respol.2017.02.004

D’Odorico, P., Davis, K. F., Rosa, L., Carr, J. A., Chiarelli, D., Dell'Angelo, J. et al. (2018). The Global Food-Energy-Water Nexus. Reviews of Geophysics, 56, 456-531. https://doi.org/10.1029/2017RG000591

David Hollenbach, S. J. (2019). Humanity in Crisis: Ethical and Religious Response to Refugees. Washington DC: Georgetown University Press.

https://doi.org/10.2307/j.ctvrnfqji

de Blij, H., \& Murphy, A. (2003). Human Geography: Culture, Society, and Space (7th 
ed.). New York: Wiley.

Dearing, J., Battarbee, R., \& Dikau, R. (2006). Human-Environment Interactions: Learning from the Past. Regional Environment Change, 6, 1-16.

https://doi.org/10.1007/s10113-005-0011-8

Diamond, J. (2005). Collapse: How Societies Choose to Fail or Succeed. New York: Viking Penguin.

Ducruet, C., Panahi, R., Ng, A. K., Jiang, C., \& Afenyo, M. (2019). Between Geography and Transport: A Scientometric Analysis of Port Studies in Journal of Transport Geography. Journal of Transport Geography, 81, Article ID: 102527. https://doi.org/10.1016/j.jtrangeo.2019.102527

Dudley, N., Parrish, J., Redford, K., \& Stolton, S. (2010). The Revised IUCN Protected Area Management Categories: The Debate and Ways Forward. Oryx, 44, 485-490. https://doi.org/10.1017/S0030605310000566

Durand, C., \& Fournier, S. (2017). Can Geographical Indications Modernize Indonesian and Vietnamese Agriculture? Analyzing the Role of National and Local Governments and Producers' Strategies. World Development, 98, 93-104.

https://doi.org/10.1016/j.worlddev.2015.11.022

Durkeim, E. (1995). Red Earth, White Lies: Native Americans and the Myth of Scientific Fact. New York: Scribner.

Economides, M. (2000). The Color of Oil: The History, the Money and the Politics of the World's Biggest Business. Houston Geological Society Bulletin, 4, 13.

Folke, C., Carpenter, S., Walker, B., Scheffer, M., Chapin, T., \& Rockström, J. (2010). Resilience Thinking: Integrating Resilience, Adaptability and Transformability. Ecology and Society, 15, 20. https://doi.org/10.5751/ES-03610-150420

Folke, C., Hahn, T., Olsson, P., \& Norberg, J. (2005). Adaptive Governance of SocioEcological Systems. Annual Review of Environment and Resources, 30, 441-473. https://doi.org/10.1146/annurev.energy.30.050504.144511

Fouberg, E. H., \& Murphy, A. B. (2020). Human Geography: People, Place, and Culture. Hoboken, NJ: John Wiley \& Sons.

Fu, B., Tian, T., Liu, Y., \& Zhao, W. (2019). New Developments and Perspectives in Physical Geography in China. Chinese Geographical Science, 29, 363-371. https://doi.org/10.1007/s11769-019-1038-y

Galvani, A. P., Bauch, C. T., Anand, M., Singer, B. H., \& Levin, S. A. (2016). Human-Environment Interactions in Population and Ecosystem Health. Proceedings of the National Academy of Sciences of the United States of America, 113, 14502-14506. https://doi.org/10.1073/pnas.1618138113

Gavin, M. C., McCarter, J., Berkes, F., Mead, A. T. P., Sterling, E. J., Tang, R., \& Turner, N. J. (2018). Effective Biodiversity Conservation Requires Dynamic, Pluralistic, Partnership-Based Approaches. Sustainability, 10, 1846. https://doi.org/10.3390/su10061846

Getis, A., Getis, J., \& Fellmann, J. D. (2008). Introduction to Geography (11th ed.). New York: McGraw-Hill.

Gordon, T., \& Webber, J. R. (2008). Imperialism and Resistance: Canadian Mining Companies in Latin America. Third World Quarterly, 29, 63-87. https://doi.org/10.1080/01436590701726509

Goudie, A. S. (2018). Human Impact on the Natural Environment. Hoboken, NJ: John Wiley \& Sons.

Graham, J., Amos, B., \& Plumptre, T. (2003). Governance Principles for Protected Areas 
in the 21st Century: A Discussion Paper. Ottawa: Institute of Governance/Parks Canada/Canadian International Development Agency.

Grigolato, S., Mologni, O., \& Cavalli, R. (2017). GIS Applications in Forest Operations and Road Network Planning: An Overview over the Last Two Decades. Croatian Journal of Forest Engineering, 38, 175-186.

Gruda, N., Bisbis, M., \& Tanny, J. (2019). Impacts of Protected Vegetable Cultivation on Climate Change and Adaptation Strategies for Cleaner Production-A Review. Journal of Cleaner Production, 225, 324-339. https://doi.org/10.1016/j.jclepro.2019.03.295

Grzymala-Kazlowska, A., \& Phillimore, J. (2018). Introduction: Rethinking Integration. New Perspectives on Adaptation and Settlement in the Era of Super-Diversity. Journal of Ethnic and Migration Studies, 44, 179-196.

Gunderson, L., \& Holling, C. (2002). Panarchy: Understanding Transformations in Human and Natural Systems. Washington DC: Island.

Hardin, G. (1998). Extensions of “The Tragedy of the Commons". Science, 280, 682-683. https://doi.org/10.1126/science.280.5364.682

Harvey, D. (1984). On the History and Present Condition of Geography: An Historical Materialist Manifesto. Professional Geographer, 36, 1-11. https://doi.org/10.1111/j.0033-0124.1984.00001.x

Heiko, B. (2009). Remote Sensing and Earth Observation. In N. Castree, D. Demeritt, \& D. Liverman (Eds.), A Companion for Environmental Geography (pp. 315-335). Sussex: Blackwell.

Hoegh-Guldberg, O., Jacob, D., Bindi, M., Brown, S., Camilloni, I., Diedhiou, A. et al. (2018). Impacts of $1.5^{\circ} \mathrm{C}$ Global Warming on Natural and Human Systems. In Global Warming of $1.5^{\circ} \mathrm{C}$. An IPCC Special Report.

Hogan, M. J. (1996). Hiroshima in History and Memory. Cambridge: Cambridge University Press.

Holland, M. B. (2012). The Role of Protected Areas for Conserving Biodiversity and Reducing Poverty. In J. Ingram, F. DeClerck, \& C. Rumbaitis del Rio (Eds.), Integrating Ecology and Poverty Reduction (pp. 225-272). New York, NY: Springer. https://doi.org/10.1007/978-1-4614-0186-5 18

Holling, C., Gunderson, L. H., \& Ludwig, D. (2002). In Quest of a Theory of Adaptive Change. In L. H. Gunderson, \& C. Holling (Eds.), Panarchy: Understanding Transformations in Human and Natural Systems (pp. 3-24). Washington DC: Island Press.

Houghton, J., Meira Filho, L., Callander, B., Harris, N., Kattenberg, A., \& Maskell, K. (Eds.) (1996). Climate Change 1995: The Science of Climate Change. Cambridge: Cambridge University Press.

Huntington, E. (1915). Civilization and Climate. New Haven, CT: Yale University Press.

Judkins, G., \& Marissa, S. (2008). Determinism within Human-Environment Research and the Rediscovery of Environmental Causation. Geographical Journal, 174, 17-29. https://doi.org/10.1111/j.1475-4959.2008.00265.x

Kemp, S. P., Palinkas, L. A., Wong, M., \& Wagner, K. (2015). Strengthening the Social Response to the Human Impacts of Environmental Change. Grand Challenges for Social Work Initiative Working Paper No. 5.

Kirby, R. S., Delmelle, E., \& Eberth, J. M. (2017). Advances in Spatial Epidemiology and Geographic Information Systems. Annals of Epidemiology, 27, 1-9. https://doi.org/10.1016/j.annepidem.2016.12.001

Kitano, H. (2002). Systems Biology: A Brief Overview. Science, 295, 1662-1664. https://doi.org/10.1126/science.1069492 
Kothari, A. (2006). Collaborative Managed Protected Areas. In M. Lockwood, G. Worboys, \& K. Kothari (Eds.), Managing Protected Areas: A Global Guide. London: Earthscan.

Krook-Riekkola, A., Berg, C., Ahlgren, E. O., \& Söderholm, P. (2017). Challenges in TopDown and Bottom-Up Soft-Linking: Lessons from Linking a Swedish Energy System Model with a CGE Model. Energy, 141, 803-817.

https://doi.org/10.1016/j.energy.2017.09.107

Le Billon, P. (2018). Oil, Resource Wars, and the Islamic State.

Lee, C. T. A., Thurner, S., Paterson, S., \& Cao, W. (2015). The Rise and Fall of Continental Arcs: Interplays between Magmatism, Uplift, Weathering, and Climate. Earth and Planetary Science Letters, 425, 105-119. https://doi.org/10.1016/j.epsl.2015.05.045

Levis, C., Flores, B. M., Moreira, P. A., Luize, B. G., Alves, R. P., Franco-Moraes, J. et al. (2018). How People Domesticated Amazonian Forests. Frontiers in Ecology and Evolution, 5, 171. https://doi.org/10.3389/fevo.2017.00171

Levtzion, N., \& Spaulding, J. (2003). Medieval West Africa: Views from Arab Scholars and Merchants. Princeton NJ: Markus Wiener.

Liu, C., Cai, W., Jia, S., Zhang, M., Guo, H., Hu, L., \& Jiang, Z. (2018). Energy-Based Evaluation and Improvement for Sustainable Manufacturing Systems Considering Resource Efficiency and Environment Performance. Energy Conversion and Management, 177, 176-189. https://doi.org/10.1016/j.enconman.2018.09.039

Liverman, D. (2004). Who Governs, at What Scale and at What Price? Geography, Environmental Governance, and the Commodification of Nature. Annals of Association of American Geographers, 94, 734-738.

Liverman, D. M., \& Vilas, S. (2006). Neoliberalism and the Environment in Latin America. Annual Review of Environment and Resources, 31, 327-363. https://doi.org/10.1146/annurev.energy.29.102403.140729

Locke, H., \& Dearden, P. (2005). Rethinking Protected Area Categories and the New Paradigm. Environmental Conservation, 32, 1-10. https://doi.org/10.1017/S0376892905001852

Lockwood, M. (2010). Good Governance for Terrestrial Protected Areas: A Framework, Principles and Performance Outcomes. Journal of Environmental Management, 91, 754-766. https://doi.org/10.1016/j.jenvman.2009.10.005

Mabogunje, A. (2015). The Development Process: A Spatial Perspective. London: Routledge. https://doi.org/10.4324/9781315658483

Manners, G. (2019). The Geography of Energy. London: Routledge. https://doi.org/10.4324/9780429265617

Marciniak, S., \& Perry, G. H. (2017). Harnessing Ancient Genomes to Study the History of Human Adaptation. Nature Reviews Genetics, 18, 659-674. https://doi.org/10.1038/nrg.2017.65

Martinez Garcia de Leaniz, P., Herrero Crespo, A., \& Gómez López, R. (2018). Customer Responses to Environmentally Certified Hotels: The Moderating Effect of Environmental Consciousness on the Formation of Behavioral Intentions. Journal of Sustainable Tourism, 26, 1160-1177. https://doi.org/10.1080/09669582.2017.1349775

McGovern, T. H. (2000). The Demise of Norse Greenland. In W. W. Fitzhugh (Ed.), Vikings (pp. 327-339). Washington DC: Smithsonian.

Messerli, B., Grosjecn, T., Nunez, L., \& Pfister, C. (2000). From Nature-Dominated to Human-Dominated Environmental Changes. Quaternary Science Reviews, 19, 459-479. https://doi.org/10.1016/S0277-3791(99)00075-X 
Millennium Ecosystem Assessment (MEA) (2005). Ecosystems and Human Well-Being: Current State and Trends: Findings of the Condition and Trends Working Group. Washington DC: Island Press.

Miller, F., Osbahr, H., Boyd, E., Thomalla, F., Bharwani, S., Ziervogel, G. et al. (2010). Resilience and Vulnerability: Complementary or Conflicting Concepts? Ecology and Society, 15, 11. https://doi.org/10.5751/ES-03378-150311

Minca, C. (2001). Postmodern Geography: Theory and Praxis. Hoboken, NJ: Wiley-Blackwell, Wiley.

Mlambo, V. (2019). Exploitation Dressed in a Suit, Shining Shoes, and Carrying a Suitcase Full of Dollars: What Does China Want in Africa? Journal of Public Affairs, 19, e1892. https://doi.org/10.1002/pa.1892

National Research Council (NRC) (2010). Understanding the Changing Planet: Strategic Directions for the Geographical Sciences. Washington DC: The National Academies Press.

Naughton-Treves, L., Alix-Garcia, J., \& Chapman, C. (2011). Lessons about Parks and Poverty from a Decade of Forest Loss and Economic Growth around Kibale National Park, Uganda. Proceedings of the National Academy of Sciences of the United States of America, 108, 13919-13924. https://doi.org/10.1073/pnas.1013332108

Naughton-Treves, L., Holland, M., \& Brandon, K. (2005). The Role of Protected Areas in Conserving Biodiversity and Sustaining Local Livelihoods. Annual Review Environment Resource, 30, 219-252. https://doi.org/10.1146/annurev.energy.30.050504.164507

Nelson, F. (2010). Introduction: The Politics of Natural Resource Governance in Africa. In F. Nelson (Ed.), Community Rights, Conservation and Contested Land: The Politics of Natural Resource Governance in Africa (pp. 3-31). London: Earthscan.

Nesterova, M. (2017). Educational Cognitive Technologies as Human Adaptation Strategies. Future Human Image, 7, 102-112.

Neuendorf, K. A., \& Kumar, A. (2015). Content Analysis. In The International Encyclopedia of Political Communication (pp. 1-10). Hoboken, NJ: John Wiley \& Sons. https://doi.org/10.1002/9781118541555.wbiepc065

Newman, G., Chandler, M., Clyde, M., McGreavy, B., Haklay, M., Ballard, H. et al. (2017) Leveraging the Power of Place in Citizen Science for Effective Conservation Decision Making. Biological Conservation, 208, 55-64. https://doi.org/10.1016/j.biocon.2016.07.019

O'Connell, E. (2017). Towards Adaptation of Water Resource Systems to Climatic and Socio-Economic Change. Water Resources Management, 31, 2965-2984. https://doi.org/10.1007/s11269-017-1734-2

Ostrom, E., Burger, J., Field, C. B., Norgaard, R. B., \& Policansky, D. (1999). Local Lessons, Global Challenges. Science, 284, 278-282. https://doi.org/10.1126/science.284.5412.278

Page, S. E. (2005). Are We Collapsing? A Review of Diamond's Collapse: How Societies Choose to Fail or Succeed. Journal of Economic Literature, 43, 1049-1062. https://doi.org/10.1257/002205105775362032

Pauliuk, S., \& Hertwich, E. G. (2015). Socioeconomic Metabolism as Paradigm for Studying the Biophysical Basis of Human Societies. Ecological Economics, 119, 83-93. https://doi.org/10.1016/j.ecolecon.2015.08.012

Phillips, M. (2017). Philosophical Arguments in Human Geography. In M. Phillips (Ed.), Contested Worlds (pp. 13-85). London: Routledge. https://doi.org/10.4324/9781315259406-2 
Pisor, A. C., \& Jones, J. H. (2020). Human Adaptation to Climate Change: An Introduction to the Special Issue. American Journal of Human Biology, e23530. https://doi.org/10.1002/ajhb.23530

Plumpton, H. J., Mayle, F. M., \& Whitney, B. S. (2020). Paleoecological Potential of Phytoliths from Lake Sediment Records from the Tropical Lowlands of Bolivia. Review of Palaeobotany and Palynology, 275, Article ID: 104113.

https://doi.org/10.1016/j.revpalbo.2019.104113

Potter, R., \& Unwin, T. (Eds.) (2017). The Geography of Urban-Rural Interaction in Developing Countries: Essays for Alan B. Mountjoy (Vol. 7). London: Routledge. https://doi.org/10.4324/9781351215381

Pritchard, B., \& Hutchinson, N. (2010). True Blue Geography. Australian Geography Teachers Association.

Rands, M. R., Adams, W. M., Bennun, L., Butchart, S. H., Clements, A., Coomes, D. et al. (2010). Biodiversity Conservation: Challenges beyond 2010. Biodiversity Conservation Science, 329, 1298-1303. https://doi.org/10.1126/science.1189138

Redman, C. (1999). Human Impact on Ancient Environments. Tucson, AZ: The University of Arizona Press.

Reyes-García, V., Fernández-Llamazares, Á., Guèze, M., Garcés, A., Mallo, M., VilaGómez, M., \& Vilaseca, M. (2016). Local Indicators of Climate Change: The Potential Contribution of Local Knowledge to Climate Research. Climate Change, 7, 109-124. https://doi.org/10.1002/wcc.374

Richard, K. (2003). Geography and the Physical Sciences Tradition. In S. Holloway, S. Rice, \& G. Valentine (Eds.), Key Concepts in Geography (pp. 23-50). London: Sage.

Robert, A., Fontaine, C., Veron, S., Monnet, A. C., Legrand, M., Clavel, J. et al. (2017). Fixism and Conservation Science. Conservation Biology, 31, 781-788.

Robison, H. (1976). A Geography of Tourism. Plymouth: Macdonald and Evans.

Rockström, J., Steffen, W., Noone, K., Persson, A., Stuart III Chapin, F., Lambin, E. et al. (2009). Planetary Boundaries: Exploring the Safe Operating Space for Humanity. Ecology and Society, 14, 32. https://doi.org/10.5751/ES-03180-140232

Rossman, E. J. (2006). A Review of: “Diamond, Jared. Collapse: How Societies Choose to Fail or Succeed". Society \& Natural Resources: An International Journal, 19, 573-575. https://doi.org/10.1080/08941920600665412

Scarano, F. R. (2017). Ecosystem-Based Adaptation to Climate Change: Concept, Scalability and a Role for Conservation Science. Perspectives in Ecology and Conservation, 15, 65-73. https://doi.org/10.1016/j.pecon.2017.05.003

Scarlett, L., \& Boyd, J. (2015). Ecosystem Services and Resource Management: Institutional Issues, Challenges, and Opportunities in the Public Sector. Ecological Economics, 115, 3-10. https://doi.org/10.1016/j.ecolecon.2013.09.013

Schoon, M., \& Cox, M. E. (2018). Collaboration, Adaptation, and Scaling: Perspectives on Environmental Governance for Sustainability. Sustainability, 10, 679.

https://doi.org/10.3390/su10030679

Sellberg, M. M., Ryan, P., Borgström, S. T., Norström, A. V., \& Peterson, G. D. (2018). From Resilience Thinking to Resilience Planning: Lessons from Practice. Journal of Environmental Management, 217, 906-918.

https://doi.org/10.1016/j.jenvman.2018.04.012

Sherman, D. (Ed.) (1991). Western Civilization: Images and Interpretations (3rd ed., Vol. 1). New York: McGraw-Hill.

Smit, B., \& Wandel, J. (2006). Adaptation, Adaptive Capacity and Vulnerability. Global 
Environmental Change, 16, 282-292. http://www.sciencedirect.com/ https://doi.org/10.1016/j.gloenvcha.2006.03.008

Soper, K. (1995). What Is Nature? Culture, Politics and the Non-Human. Cambridge, MA: Blackwell.

Stobbelaar, D. J., \& Pedroli, B. (2011). Perspectives on Landscape Identity: A Conceptual Challenge. Landscape Research, 36, 321-339. https://doi.org/10.1080/01426397.2011.564860

Stolton, S. (2010). Protected Areas: Linking Environment and Wellbeing. In Arguments for Protected Areas: Multiple Benefits for Conservation and Use (pp. 1-12). London: Earthscan.

Strahler, A., \& Archibold, O. (2008). Physical Geography: Science and Systems of the Human Environment. New York: Wiley.

Strahler, A., \& Archibold, O. W. (2011). Physical Geography: Science and Systems of the Human Environment (5th Canadian ed.). Mississauga, ON: John Wiley \& Sons Canada.

Talberg, A., Christoff, P., Thomas, S., \& Karoly, D. (2018). Geoengineering Governanceby-Default: An Earth System Governance Perspective. International Environmental Agreements: Politics, Law and Economics, 18, 229-253. https://doi.org/10.1007/s10784-017-9374-9

Tellman, B., Bausch, J., Eakin, H., Anderies, J., Mazari-Hiriart, M., Manuel-Navarrete, D., \& Redman, C. (2018). Adaptive Pathways and Coupled Infrastructure: Seven Centuries of Adaptation to Water Risk and the Production of Vulnerability in Mexico City. Ecology and Society, 23, 1. https://doi.org/10.5751/ES-09712-230101

Thomas, V. (2017). Climate Change and Natural Disasters: Transforming Economies and Policies for a Sustainable Future (p. 158). New York: Routledge. https://doi.org/10.4324/9781315081045

Thompson, J., \& Scoones, I. (2009). Addressing the Dynamics of Agri-Food Systems: An Emerging Agenda for Social Science Research. Environmental Science \& Policy, 12, 386-397. https://doi.org/10.1016/j.envsci.2009.03.001

Thornton, T. F., Puri, R. K., Bhagwat, S., \& Howard, P. (2019). Human Adaptation to Biodiversity Change: An Adaptation Process Approach Applied to a Case Study from Southern India. Ambio, 48, 1431-1446. https://doi.org/10.1007/s13280-019-01225-7

Timmer, V., \& Juma, C. (2005). Taking Root: Biodiversity Conservation and Poverty Reduction Come Together in the Tropics. Environment, 47, 24-44. https://doi.org/10.3200/ENVT.47.4.24-44

Tseng, M. L., Chiu, A. S., \& Liang, D. (2018). Sustainable Consumption and Production in Business Decision-Making Models. Resources, Conservation and Recycling, 128, 118-121. https://doi.org/10.1016/j.resconrec.2017.02.014

Tu, J. (2011). Spatially Varying Relationships between Land Use and Water Quality across an Urbanization Gradient Explored by Geographically Weighted Regression. Applied Geography, 31, 376-392. https://doi.org/10.1016/j.apgeog.2010.08.001

Tull, D. M. (2006). China's Engagement in Africa: Scope, Significance and Consequences. The Journal of Modern African Studies, 44, 459-479. https://doi.org/10.1017/S0022278X06001856

Turner, M. (2003). Methodologies Reflections on the Use of Remote Sensing and Geographic Information Science in Human Ecology Research. Human Ecology, 31, 255-279. https://doi.org/10.1023/A:1023984813957

UNDP (2011a). Towards Human Resilience: Sustaining MDG Progress in an Age of 
Economic Uncertainty. New York: UNDP.

UNDP (2011b). Human Development Report 2011 Sustainability and Equity: A Better Future for All. New York: UNDP.

UNEP-WCMC (2008). State of the World's Protected Areas: An Annual Review of Global Conservation Program. Cambridge: UNEP World Conservation Monitoring Centre.

von Seggern, J. (2021). Understandings, Practices and Human-Environment Relationships-A Meta-Ethnographic Analysis of Local and Indigenous Climate Change Adaptation and Mitigation Strategies in Selected Pacific Island States. Sustainability, 13, 11. https://doi.org/10.3390/su13010011

Wegenast, T., \& Schneider, G. (2017). Ownership Matters: Natural Resources Property Rights and Social Conflict in Sub-Saharan Africa. Political Geography, 61, 110-122. https://doi.org/10.1016/j.polgeo.2017.07.007

Wilson, V. (2016). Research Methods: Content Analysis. Evidence-Based Library and Information Practice, 11, 41-43. https://doi.org/10.18438/B8CG9D

Worboys, G., \& Winkler, C. (2006). Natural Heritage. Managing Protected Areas, a Global Guide. UK: IUCN.

Yang, Z., Nguyen, V. T., \& Le, P. B. (2018). Knowledge Sharing Serves as a Mediator between Collaborative Culture and Innovation Capability: An Empirical Research. Journal of Business \& Industrial Marketing, 33, 958-969.

https://doi.org/10.1108/JBIM-10-2017-0245

Zhang, S., Wang, Z., \& Zhao, X. (2019). Effects of Proactive Environmental Strategy on Environmental Performance: Mediation and Moderation Analyses. Journal of Cleaner Production, 235, 1438-1449. https://doi.org/10.1016/j.jclepro.2019.06.220 